\title{
THE ROLE OF ELITES IN CREATING CAPITALIST HEGEMONY IN POST-OIL BOOM INDONESIA
}

\author{
Yoon Hwan Shin
}

The rapid growth of the Indonesian economy during the 1970s accompanied the emergence of what I called elsewhere a new capitalist class. ${ }^{1}$ This class differs from its pre-New Order counterpart in many respects. ${ }^{2}$ Although ethnic Chinese remain a dominant segment, those who comprise the capitalist class have increasingly included a substantial number of indigenous (pribumi) business people, who have accumulated sufficient capital to affect the fate of Indonesian capitalism and have entrenched themselves deep in strategic sectors of the economy.

It is important to note, however, that the development of this new capitalist class has come about in a sociopolitical and cultural environment that is amiable neither to capitalism nor to the Chinese minority. When the Indonesian economy encountered economic crises in the 1980s, the disparity between the economic prowess of the new capitalists and their political and ideological weaknesses loomed large. The increasing role of the private sector as the savior of the post-oil boom economy was called for more emphatically than ever, but antiChinese sentiment and lack of a "capitalist hegemony" in Indonesian society constrained the active contribution of the new capitalists. ${ }^{3}$ It was against this contradictory backdrop that

\footnotetext{
1Yoon Hwan Shin, "Demystifying the Capitalist State: Political Patronage, Bureaucratic Interests, and Capitalistsin-Formation in Soeharto's Indonesia" (Ph.D. diss., Yale University, 1989).

2Ibid., chap. 6. See also Richard Robison, Indonesia: The Rise of Capital (Sydney: Allen and Unwin, 1986), p. 3, and Yuri Sato, "The Development of Business Groups in Indonesia, 1967-1989" (Master's thesis, University of Indonesia, 1989).

${ }^{3}$ Antonio Gramsci, Selections from the Prison Notebooks, ed. and trans. Quintin Hoarse and Geoffrey Norwell Smith (New York: International Publishers, 1971). Here I follow Allex Callinicos in defining Gramsci's hegemony: "an 'organizing principle,' or world-view (or combination of such world-views), that is diffused by agencies of ideological control and socialization into every area of daily life," or "this prevailing consciousness ... internalized by the broad masses." "As all ruling elites seek to perpetuate their power, wealth, and status," Callinicos explains, "they necessarily attempt to popularize their own philosophy, culture, morality, etc. and render them unchallengeable, part of the natural order of things." See Allex Callinicos, Gramsci's Marxism (London: Pluto Press, 1976), p. 39. For an opposing interpretation of Gramsci's hegemony, see Anne Showstack Sassoon, "Hegemony,
} 
political and business elites and procapitalist intellectuals came to the fore to advocate a market-oriented economic system and ideology. Capitalist hegemony must be created by noneconomic forces, especially by the state, as John Saul found in postcolonial societies, because these societies lack the time and experience required to develop a capitalist culture "slowly and surely." 4

The creation of capitalist hegemony could not be more opportune than in post-oil boom Indonesia. Substantively, the sluggish and strained economy called upon the private sector to undertake the leading role in economic growth, which had been played by the state with its rich oil revenue. Furthermore, the growing frustration and aggression among small-scale business people and the popular sector had to be politically and ideologically accommodated to provide secure situations for the new capitalists and multinationals to invest.

The "ideological modes of economic domination" described here refer to the political and cultural efforts elites undertake to insure and perpetuate the economic dominance of an emerging new capitalist class. That these efforts were increasingly evident in the $1980 \mathrm{~s}$ reflects that Indonesian capitalism is moving into a more stabilizing stage with a supportive ideology. I discuss in this paper: (1) the sociopolitical implications of the recent trend toward interracial economic cooperation; (2) the dissemination of capitalist ideas and ethics among business people, intellectuals, and government officials; and, most importantly, (3) the phaseout of anti-Chinese, indigenist economic policies and their implications.

\section{Toward a National Business Class}

Since independence, the concept of private capitalism has had negative connotations in Indonesia. Because the Indonesian usage of the term capitalism often accompanies such modifiers as free fight after Sukarno used it that way, many Indonesian elites exploited the term politically and implanted connotations of inherent chaos, unfairness, and selfishness in it. Their suspicion of capitalism was frequently expressed in creative but unsubstantiated conceptual forms. During Parliamentary Democracy, there was Assatism; Sukarno popularized communalistic Marhaenism; now under the New Order, much ink has been spilled to debate the Pancasila Economic System (Sistem Perekonomian Pancasila). These expressions, despite the different emphases and nuances among them, share at least one connotation: a hatred of a social stratum that the indigenous society lacks and that was and is occupied by the former colonizers and their collaborators. An economic system that leaves or helps them go their way was believed to undermine the well-being of the indigenous population. Thus alternative ideas were mobilized and put to test. On every trial, however, the result was dismal. It is against this hostile historical and social backdrop that the new capitalists, appearing more balanced in racial representation than before, have emerged in the New Order and have been remarkably successful in taking root in the Indonesian economy and, to a lesser degree, in society.

The ideological efforts to create and maintain a stable capitalist system are succinctly expressed in one concept, pengusaha nasional (national entrepreneur), which is replacing previously popular, racial terms to designate business people belonging to different social and economic groups. The stress is on the imported word nasional, which is antithetical to asli or

War of Position and Political Intervention," in Approaches to Gramsci, ed. Ann Showstack Sassoon (London: Writers and Readers, 1982).

4"The State in Postcolonial Societies: Tanzania," in the Socialist Register 1974, ed. Ralph Miliband and John Saville (New York: Monthly Review Press; London: Merlin Press, 1974); reprinted in The State and Revolution in Eastern Africa: Essays by John S. Saul, ed. John S. Saul (New York and London: Monthly Review Press, 1979), p. 170. Sce also Hamza Alavi, "The State in Post-Colonial Societies: Pakistan and Bangladesh," New Left Review 74 (1972). 
pribumi. This observation does not imply that this officially promoted term will soon remove such still prevalent terms as nonpribumi, orang Cina, orang Tionghoa, or WNI (keturunan) Cina (or, simply, WNI) from everyday conversation. ${ }^{5} \mathrm{I}$ am simply arguing that the disappearance of these terms from the media and government decrees will at least discourage state officials, business people, and intellectuals from making issues of the Chinese problem. Reduced usage also marks a beginning of the end for the government to blame only the Chinese for their "exclusivism." It does not, of course, guarantee that ordinary Indonesians will soon accept the new usage. Even so, it should be seen as an effort by the state and the new capitalists to create the hegemony of capitalist ideology and culture in society. The term implicitly suggests that the entrepreneurs, whether Chinese or indigenous, serve the common interests of the nation, not their respective racial interests. On a general level, it also conveys the concept that capitalism realizes the interests of all, not just the capitalists' class interests.

The nomenclatural development has been substantiated by a change in the world of business, that is, the increased commercial cooperation among the private business people, especially between pribumi and Chinese. ${ }^{6}$ In a sense, it is an acceptable compromise between the sobering reality of the invincible Chinese economic position and the unwarranted ideal of indigenism.

This cooperation takes the forms of an intrafirm partnership and an interfirm market cartel. Joint ventures among big corporations now go beyond racial or ethnic differences. The partnership between pribumi and nonpribumi is not new in Indonesia, but what I refer to here is a somewhat sincere one, unlike the cukong, Ali-Baba, and Baba-Ali arrangements, which are convenient bypasses of legal obstacles. With more pribumi in business and with more Chinese confident in the New Order's commitment to the capitalist path, business people of the two races have become engaged in a more lasting and earnest form of business partnership. In this new form, the indigenous partner is not merely a political contributor but a true partner in ownership and management.

Most of the Chinese big business people seem to have increasingly realized that their exclusive domination of the economy would spread sentiments of economic indigenism and eventually influence the policy making of the state, the signs of which surfaced in the wake of the Malari affair. In this sense, it can be argued, it is in their economic as well as political interest to see a strong indigenous business sector develop. The establishment of a powerful, racially intertwined economic class may revive an anticapitalist mood in society but will help prevent racist feelings from besieging the indigenous population. As long as the military is firmly in power, the Communists will never be able to regain political vigor. By contrast, racial prejudices would easily inflame social unrest and even gain influence among the governing elite within the state.

\footnotetext{
${ }^{5}$ Both orang Cina and orang Tionghoa refer to a Chinese; the former is considered pejorative by the Chinese Indonesians. Immediately after Soeharto assumed power, his regime deliberately discouraged the use of orang Tionghoa, which is recently regaining ground. See Charles A. Coppel, Indonesian Chinese in Crisis (Kuala Lumpur: Oxford University Press, 1983), p. 157. WNI, pronounced weh-en-ih, stands for Warga Negara Indonesia, literally meaning an Indonesian citizen but, in practice, referring only to ethnic Chinese who have obtained Indonesian nationality.

${ }^{6} \mathrm{~A}$ phrase coined to express the Chinese-pribumi cooperation in business is "pembauran di bidang usaha." Pembauran, literally mixing, association, or social intercourse, has been primarily used to mean cultural assimilation of "non-native" Indonesians. In business, however,_-"di bidang usaha" meaning "in the business field"-pembauran does not carry the connotation that a distinctive subculture integrates into the larger universal culture. Instead, it simply means mutual cooperation in business between the two racial groups.
} 
Today, many Chinese companies have pribumi as managers or shareholders and vice versa. Admittedly, with nationalist and discriminatory policies still on and off, concerns about expediency could become a major reason for the interracial working relationship. But as I will elaborate in the final section of this article, such policies in the New Order have had little impact upon the big businesses of the Chinese. Thus the recent tendency toward business pembauran seems to be an outcome of the new capitalists' conscious realization that both their pribumi and Chinese fractions can benefit from the greater economic share of the pribumi.

This consciousness is displayed in many de facto market cartels formed in the industries developed along the state's import-substitution strategy. The strategy gives significant privileges to the existing companies in these industries by demanding higher costs for the companies that seek new entry. The number of companies operating in these sectors is kept relatively small, which protects inefficient and uncompetitive firms. Although the less competent firms could lose out in limited competition within these sectors, it is also true that the more competent firms have found it harmful to drive out completely their weak competitors, which are often pribumi owned. The existence of these indigenous companies may not only give an appearance of a healthy competition, instead of a Chinese monopoly, but also provide the state with the pretext to maintain its continuous protection of the industrial sectors. The new capitalists may believe that their political weakness can be compensated by increased class cohesiveness and by their deep entrenchment in the economy. To this end, mutual cooperation and interaction among the bigger corporations became increasingly noticeable in the 1980 s.

\section{Ideological Role of Elites in Creating the Hegemony of Capitalism}

The scheme the new capitalists designed to obtain an acceptable dominance has been supported by many elements of the upper class, including high government officials, business people, academicians, and journalists. No doubt, these groups share common interests and concerns behind their near-united support for the scheme. But rather unusual in the 1980s was that the campaign was carried out in exceptionally open ways.

The catalyst was the recession of the early 1980s, which squeezed budgetary resources for public projects and various programs that doled out credit to the already hard-pressed, small, indigenous companies. Facing this plight, the state called on big business, including the Chinese, first, to move the economy out of the recession, and, second, to take over the task of helping the small and medium pribumi-owned companies. During the early 1980s, an ideological groundwork was laid to facilitate the state's final abandonment of the racist interpretation of the "weak economic group" in implementing economic policy. Naturally, those who were most affected by, or related to, the economic situation took charge of the ideological task.

I call the concerted effort ideological in the sense that all the suggestions and justifications they gave to the policy change remained rhetorical and, in effect, protected the interests of the new capitalists. It was carried out in the form of academic debates, public talks, and official statements. The participants were overwhelmingly united in their intent. Thus it should be called instead a campaign to promote or indoctrinate capitalist ideas. Its core arguments included denunciation of the small pribumi capitalists' lack of entrepreneurial spirit and of their dependence on government projects and racist policies and, at the same time, a eulogy of the free and open market solution to the economic stagnation; the constructive role of Chinese entrepreneurs in the Indonesian economy; the voluntary assistance by big business to small business; and, generally, the efficacy of the private sector 
and big business. Various associations of indigenous businessmen were in the forefront of the campaign.

The Indonesian Chamber of Commerce and Industry (KADIN) demonstrated the most obvious interest in accepting the enhanced role of the private sector in business affairs. In the early 1980s, the state, in a symbolic gesture, designated KADIN as the only legitimate social institution to provide assistance to small and medium (mostly pribumi-owned) companies. After that, KADIN, which was originally organized to protect pribumi business interests, collected funds primarily from Chinese entrepreneurs and distributed them through its regional offices. Reporting to President Suharto, who called for a consortium for that purpose, KADIN's Vice-Chairman Probosutedjo informed him that Rp. 5 billion had already been collected at the initiation of two leading Chinese entrepreneurs, Liem Sioe Liong and William Soeryadjaya. ${ }^{7}$ Each time when they distributed the funds, KADIN representatives did not fail to stress, as the most important means to success, the creativity and hard work of the entrepreneurs themselves rather than outside support.

It was also in this context that a special coordinating body emerged to support the smallscale, pribumi-owned companies. The Indonesian Union of Leading Entrepreneurs (IPPI, Ikatan Pemuka Pengusaha Indonesia), upon its founding in September 1980, declared that its members, consisting of both leading Chinese and indigenous entrepreneurs, would not bid for government tenders valued over Rp. 1 billion. ${ }^{8}$ The figure was ten to twenty times higher than the minimum value of government contracts and purchases in which Keppres No. 14/1979 permitted the big pribumi or Chinese-owned businesses to participate. Immediately after its organizational meeting in September, IPPI secured Rp. 3 billion as funds to be credited to small pribumi business people. ${ }^{9}$ But because the amount provided to each recipient barely reached $\mathrm{Rp} .100,000$ and because the funds were given out with no collateral, it seemed obvious that they were aimed to show the good will of big business rather than to make a sincere effort to support entrepreneurial aspirants. These "charity" activities became less publicized after 1980-1981.

At this juncture, various proposals were put forward about how to forge and increase cooperative relationships between big and small business. ${ }^{10}$ The so-called bapak angkat system was interesting. ${ }^{11}$ Because bapak angkat means "adoptive father," the idea was patrimonialistic: a big company should help a specially selected group of small companies by giving credit, contracts, management advice, job training, and other assistance. Because the Department of Industry coined the concept, however, no notable progress has been reported beyond interpreting the system to mean whatever links already exist between big and small companies-a usual end for many proposals and debates in Indonesian business.

KADIN has also accelerated its campaign to embrace and involve more Chinese in the organization. For instance, the Executive Board of Directors of KADIN for the term 19821985 had at least three Chinese as chairmen or vice-chairmen of its fourteen compartments. ${ }^{12}$ Among them, quite revealingly, were the Compartment of Budget and Treasury,

\footnotetext{
${ }^{7}$ Antara, July 20, 1980.

$8_{\text {Berita Buana, October 23, } 1980 .}$

${ }^{9}$ Antara, October 19, 1980.

${ }^{10}$ See, for example, Kwik Kian Gie, "Pengusaha Kuat Yang Harus Membantu Yang Lemah," Kompas, January 22, 1981; and a newspaper article entitled, "Perusahaan Kecil Dimata Konsultan" in Berita Buana, February 12, 1979.

${ }^{11}$ Pelita, December 30, 1980.

${ }^{12}$ Indonesian Chamber of Commerce and Industry, "Information Guide to the Organization of Kadin Indonesia," Jakarta, 1983, pp. 45-52.
} 
chaired by Mochtar Riady, and that of Small Business Development, chaired by William Soeryadjaya. The compartment led by Soeryadjaya aimed to direct various support from the large (mainly Chinese-owned) industries to the small (pribumi-owned) industries. Its vicechairman was R. Agung Laksono, the head of the Indonesian Young Entrepreneurs' Association (HIPMI). HIPMI was one of the most outspoken supporters of indigenist public policy.

The most remarkable transformation took place in the Indonesian Indigenous Businessmen's Association (HIPPI: Himpunan Pengusaha Pribumi Indonesia). As its name indicates, it had been an exclusively pribumi organization until 1984. Its head (Ketua Dewan Pembina) was again Probosutedjo and, despite his inconsistent and confusing position, had often made demands and complaints in outright favor of the pribumi business people. But when Benny Moerdani called for a halt to use of the terms pribumi and nonpribumi, HIPPI changed the word pribumi to putera (son or prince) in the organization's name. ${ }^{13}$ Later Probosutedjo explained that HIPPI has a "broad and big" meaning. The word putera in HIPPI does not mean merely "child" (anak) but "a patriot who loves his motherland, its people and country." 14 "Thus," he continued, "for whoever is prepared to serve the nation, regardless of race or size of business, the door to membership is open wide." 15 The only qualification to join HIPPI was "truly having the Pancasila spirit." 16 Now he was suggesting precisely what the state wished for. In fact, a week later, Coordinating Minister of Public Welfare, Alamsjah Ratu Prawiranegara, used very similar phrases to second Probosutedjo's idea; "Every Indonesian citizen, regardless of place of origin, religion, or conviction, is an Indonesian putera who must be loyal to Pancasila and the 1945 Constitution and has the obligation and responsibility to serve his nation and country." 17 What Probosutedjo quoted Vice-President Umar Wirahadikusumah to have said retained a more concrete recommendation "that the pribumi businessmen can work together with any group and learn from able and strong businessmen."18

Probosutedjo was a man of his word, at least on this matter. When HIPPI reshuffled its leadership one week later, Agus Nursalim, his long-time Chinese business associate, was included in the executive council, and an obscure figure of Chinese name, Nurdani Latif (Lie Hong Wi), was appointed the treasurer. He assessed their spirit of Pancasila by saying, "these people already became good Indonesian putera." 19 A more concrete plan came to life two months later. In November, HIPPI established a company in Medan to implement "pembauran in business between big and small entrepreneurs as well as between entrepreneurs of Indonesian origin and those of foreign origin." 20 The company, interestingly named P. T. Asperindo (Asli Putera Indonesia), had two Chinese directors and a Chinese advisor (penasehat).

The group that demanded and benefited the most from the nationalist economic policy was the Indonesian Young Entrepreneurs' Association (HIPMI, Himpunan Pengusaha

\footnotetext{
${ }^{13}$ Susumu Awanohara, "The Perennial Problem," Far Eastern Economic Review, September 6, 1984, p. 27.

${ }^{14}$ Antara, December 22, 1984.

${ }^{15}$ Ibid.

16 Sinar Harapan, October 24, 1984 (emphasis mine).

${ }^{17}$ Sinar Harapan, October 30, 1984.

${ }^{18}$ Merdeka, October 24, 1984 (emphasis mine).

${ }^{19}$ Antara, September 3, 1984.

20 Merdeka, November 13, 1984.
} 
Muda Indonesia). But even in HIPMI, it became more apparent as time went on that the members realized and appreciated the necessity of Chinese support in materializing the government's pro-pribumi programs. They needed more Chinese help than did, probably, any other group of pribumi businessmen because of lack of business experience, shortage of capital, and their excessive dependence on political connections. I learned from interviews with several young pribumi and Chinese businessmen that the younger generation of the two ethnic groups cooperated as much as their seniors did. Before the election of HIPMI's chair due in early 1986, some young Chinese businessmen actively campaigned for a certain candidate with a less racist platform.

HIPMI's anti-Chinese outlook toned down substantially as KADIN became as important a patron as the state in the post-oil boom economy. Its members had to accept Chinese business people as sources of credit and donations and in their role as "bapak angkat," however empty its practical meaning was. Perhaps more important was the polarization of the young indigenous business community, which was precipitated by Keppres no. 10/1980. The presidential decision gave the children around the most powerful group extraordinary opportunities to obtain big government contracts, whereas the immediately ensuing recession drove out numerous less powerful, young business people. ${ }^{21}$ In tandem, high government officials-including the so-called nationalists-economists, and journalists launched deliberate all-out attacks on HIPMI. In retrospect, these attacks were only a prelude to what was soon to come. In explaining Keppres nos. 29/1984 and 30/1984, which replaced the previous presidential decrees on small-scale government suppliers and contractors, government officials included in the category of the "weak economic group" "those nonindigenous Indonesians who have assimilated."22

Although they chose words cautiously, government officials were clear on what they wished to convey to the HIPMI members. The powerful State Secretary Soedharmono urged them to "apply to their work methods that are pragmatic and practical but are also spirited by the concept of high national idealism."23 The ambiguity of this statement cleared when he added the following: "You should not accustom yourselves to fiddling around with [government] facilities and living on distributing imported goods. Opportunism and 'protectionist' life-styles, which characterize the attitudes of some HIPMI members, must be thrown away." It is important to notice that it was not the technocrats but the so-called nationalists who led the campaign to undermine the raison-d'être of HIPMI. It implies that because the technocrats would possibly invite backlash, the nationalists acted in this case as defenders of the common interest of the state.

Another minister belonging to the nationalist camp, Minister of Internal Affairs Soepardjo Roestam, declared that the day was gone when "the government helped you with decrees as the mother fed [the baby] with milk,"24 so "you should not rely on the capacity of others including the government." 25 A less powerful official, Governor of Greater Jakarta R. Soeprapto, spoke in the same vein when he said, somewhat beseechingly, "HIPMI can explore new business areas [rather than government contracting] in an effort to [support the government in tackling] the problem of unemployment" and, "as a government partner, can help the growth of the weak economic group in terms of capitalization, marketing as well as

\footnotetext{
${ }^{21}$ Shin, "Demystifying the Capitalist State," chap. 7, especially pp. 264-74.

22Manggi Habir, "Protecting Their Interests," Far Eastern Economic Review, May 10, 1984, p. 73.

${ }^{23}$ Merdeka, May 8, 1984.

${ }^{24}$ Kompas, August 1, 1984.

${ }^{25}$ Antara, July 31, 1984.
} 
managerial skills." ${ }^{26}$ As an ironical distortion, Soeprapto ignored the fact that HIPMI itself consisted overwhelmingly of "the weak economic group." For example, in the better-off Greater Jakarta (Jaya) branch, 70 to 80 percent of the HIPMI members belonged to this category, whereas the remainder were medium and strong business people. ${ }^{27}$

It seemed that HIPMI also failed to gain sympathy from the parliament, DPR. Receiving a visit by HIPMI's Jaya branch leaders, the chairman of the provincial parliament of Jakarta, Soedarsono, was more straightforward than the bureaucrats in giving advice. He said that "the members of HIPMI Jaya must be capable of developing into self-reliant entrepreneurs without depending on the government, because dependence will bring loss back to them and weaken their activity and creativity as entrepreneurs." ${ }^{28}$ Its vice-chairman, H. M. Jufrie, remarked that according to his own observation, most HIPMI Jaya members are active only in the areas of procurement and service and "should be more oriented toward industrial sectors." Another vice-chairman, H. Wim Salamun, ridiculed them by pointing out that "HIPMI should be a little more selective in accepting its members. . . Do not accept those adventurists (pengusaha avonturis) who ruin Hipmi's good reputation."29

By the end of 1984, HIPMI seemed finally to give up its effort to mobilize support from outside. Thus the chairman, Agung Laksono, a political aspirant, began to echo what the government officials and business people had suggested to him. In the ceremony officially accepting thirty-four new members, Laksono warned that "government projects should not be the only business area that interests you," adding that "as an entrepreneur, you must be able to create your own business, which will help the government in augmenting employment." 30 Probosutedjo, who used to enjoy the spotlight by repeating statements sympathetic to the pribumi, looked like a born-again entrepreneur when he said, "The buildup of the weak entrepreneurs should not be carried out through state policies." ${ }^{11}$ This statement was the best and final summary of the position the policymakers and businessmen wanted to convey to the small pribumi contractors.

In sharp contrast, the morale of big business was boosted by the aggravated situation of the economy and, hence, the credentials it received from various sectors of the society as its savior. If government officials, except the technocrats, were hesitant to acknowledge the state's own responsibility for the country's economic plight, they agreed with those economists who placed their trust in the private sector.

Universities, newspapers, and business organizations organized numerous seminars and symposia to discuss how to develop entrepreneurship and promote exports.32 Business

\footnotetext{
${ }^{26}$ Ibid. See also, Antara, November 10, 1984.

${ }^{27}$ Berita Buana, August 2, 1984.

${ }^{28}$ Merdeka, October 24, 1984.

29 Ibid.

${ }^{30}$ Suara Karya, November 12, 1984.

${ }^{31}$ Merdeka, December 29, 1984. The Indonesian text reads, "Pembinaan atas pengusaha yang lemah hendaknya jangan dilakukan secara politis." It is interesting to note that politis in Indonesian can mean either "political" or "in terms of policy." It was clear that Probosutedjo meant the latter from the remark that "if the government continues to give credit, the [weak] businessmen will be dragged in an undesirable direction."

${ }^{32}$ For example, Suara Karya, a Golkar-controlled newspaper, organized a huge seminar in February 1984, in which 250 people participated. The participants included most former and present ministers of economic affairs, other ministerial-level government officials, leading business people, economists, and journalists. Two of four panels addressed the issues of "The Business Climate and the Role of the Private Sector" and "Stimulating NonOil Exports and Trade Regulations." The papers were published as Peranan Dunia Usaha Dalam Repelita IV Jakarta: Penerbit Suara Karya, 1984). Compare the dominantly "liberal" tones of the proposals to the more or
} 
schools sponsored by the government and the private sector became increasingly popular, and model entrepreneurs were praised and invited to give public talks. The mass media regularly provided forums for debates on economic issues, including monopoly and oligopoly, the Pancasila economic system, development strategy, state interventionism, the weak economic group, and so forth. All these academic activities quickly spread an atmosphere of economic crisis and created a sense that something should be done. In one sense, the consensus was predetermined: that is, the state was an obstacle (penghambat) to structural adjustment and was itself an inefficient sector wasting national resources. A solution was easily found, namely, that the private sector should be given the mission of saving the economy from the crisis. This rather obvious conclusion yielded several popular concepts, which, at their core, praised the market economy. While they reflected the changing structure of Indonesian capitalism, they, in turn, contributed to expediting the change. In this regard, the intellectual contribution corresponds precisely to what Hamza Alavi and John Saul saw as the ideological role of the postcolonial state in creating capitalist hegemony.

The key concept summarizing the academic efforts is comparative advantage (keunggulan komparatif). Borrowed from the liberal theory of international trade, this term, when applied to the Indonesian case, stresses the labor-intensive manufacturing industry as the strategic sector for promoting exports. The proponents included most technocrats and liberal economists and, interestingly, some "turncoats" from the nationalist economist group. ${ }^{33}$ Inspired by the economic success of the East Asian Newly Industrializing Countries, and pressed by the aggravating balance-of-payments problem, they looked to increasing exports as the solution. But because oil exports proved too inconsistent and because the international prices of other primary exports were also fluctuating violently, the proponents suggested that Indonesia's comparative advantage be based on her cheap and abundant labor. The low quality of Indonesian labor could stand in the way of this solution as well. But because Indonesia's options were extremely limited, economists pushed all the harder in this direction and harshly criticized what was collectively called the "high-cost economy" (ekonomi biaya tinggi). The state is, of course, chiefly responsible for creating and maintaining the high-cost economy.

In the business sector, the comparative advantage school is less refined in its arguments and more supportive of the status quo than its economic gurus. On two occasions, when debates on the issues of monopoly and the weak economic group became heated, the followers of this school lined up to support monopolies and big corporations with some qualifications. And the conclusions from these debates were in near-unanimous favor of them. Therefore, the search by the academicians for an alternative development strategy ended by promoting the interests of the new capitalists, who were strongly represented in the big businesses, monopolies and oligopolies, and the light manufacturing sector. ${ }^{34}$ The irony is that most of

less indigenist and statist ones of the seminar held nine years earlier on "Strategies to Build up the National Private Entrepreneurs," Seminar Strategi Pembinaan Pengusaha Swasta Nasional, Centre for Strategic and International Studies, May 29-31, 1975 (Malang, Indonesia: Parangan Press, 1975). Numerous workshops and seminars were also organized by Kompas and Sinar Harapan. See, for example, Kompas, August 23, 1985 and September 9 , 1985. See also, Kompas, September 11 and 12, 1985 for its long summaries of a symposium organized by the Faculty of Economics, University of Indonesia.

${ }^{33}$ Although the quotations that follow in the text are drawn heavily from peranakan Chinese intellectuals, the same ideas were shared by most economists and business observers, not to mention the technocrats. Other evidence hinting at the consensus is the wide and intense coverage the leading newspapers and magazines gave to their criticisms and suggestions.

${ }^{34}$ Therefore, the theoretical supports served as an apologetic justification to the existing and increasing oligopolies that are not necessarily efficient or competitive. As Hal Hill found recently, the enormously high 
these big business groups were the creation of the state-initiated strategy of import-substitution industrialization on which the liberal economists launched heavy attacks.

Some economists and business observers were quick to argue that export promotion requires the development of equivalents to the general trading companies, sogo shosha, of Japan. ${ }^{35}$ To compete with the multinationals in the international as well as domestic markets, they contended, Indonesia, too, needs big corporations that have an advantage in productivity, costs, and marketing. An evident twist in this proposal is that they emphasized only the size of the Japanese general trading companies while avoiding mention of their outward orientation and remarkable cost-saving efficiency in production and marketing, which Indonesian big business corporations largely lack. Attentive to the guiding role of the Japanese state in leading exports, they also argued that the Indonesian state must assume the same role in creating favorable environments and providing infrastructures. Yet considering the precisely opposite role the Indonesian state has played, the idea of "Indonesia Inc." again would be too wishful a concept to materialize. ${ }^{36}$

Wibisono also maintained that two types of monopolies and oligopolies should be distinguished. ${ }^{37}$ One he called command monopoly, which is enforced 'from 'above,' with political 'backing' and a 'command' mechanism." 38 This type, mostly found in the public sector, is the one at which the criticisms of monopoly should be directed. But the other type, the "market oligopolies," must be encouraged, because they are "the outcome of healthy, honest, free, and open competition, reflect efficiency, productivity, and creativity, and benefit consumers by providing positive services for consumers' needs." In a somewhat convincing article, he gave specific examples of the market oligopolies, which were almost exclusively controlled by, in my term, the new capitalists. As industries in which free competition created an oligopolistic situation, he listed batteries, clove and regular cigarettes, milk, film, toothpaste and detergents, polyester and rayon synthetic fibers, paint, motorcycles, flat and safety glasses, monosodium glutamate (MSG), and such auto parts as tires, batteries, and spark plugs. Although he took into account neither "nonprice competition" and government protection as crucial factors in .creating the oligopolies ${ }^{39}$ nor their negative effects on consumer prices and employment, ${ }^{40}$ his notion of market oligopoly contributed effectively to justifying, the role of big business.

"seller concentration" of Indonesia is not related to efficiency but to government protection. In addition, Indonesia remains, perhaps, the most concentrated economy that Hill knew of in the developing countries, although he found it declining slightly between 1975 and 1983. See Hal Hill, "Concentration in Indonesian Manufacturing," Bulletin of Indonesian Economic Studies 23 (2) (1987): 80-82, 98.

35 "Trading House Nusantara, Seperti Apa?" Informasi 12 (1981): 12-20; "Jaringan Sogo-Shosha," Informasi 5 (1982): 3-23; Christianto Wibisono, Kearah Indonesia Incorporated, 2 vols. (Jakarta: Yayasan Management Informasi, 1985).

${ }^{36}$ Christianto Wibisono borrows from "Japanese Inc." to conceptualize "Indonesian Inc.," in which the national economy can be run as if it were an incorporated company with the state as the management and the private sector as the production line. Ibid.

${ }^{37}$ Christianto Wibisono, "Oligopoli Pasar dan Monopoli Komando," Kompas, January 31, 1985; see also, "Anatomi Tiga Kelompok Industri," Informasi 3 (1985): 5-19.

${ }^{38}$ Wibisono, "Oligopoli."

${ }^{39}$ For details of this criticism, see H. M. T. Oppusunggu, "Semedi Ekonomi," Sinar Harapan, February 14, 1985. According to Oppusunggu, nonprice competition refers to various "means of competition [other than low prices] such as service, warranty, credit, advertisement, packing, and so forth," which weaken the competitiveness of new, mainly small, producers.

${ }^{40}$ For details, see Hasibunan, "Oligopoli di Indonesia: Kasus Sektor Industri," Prisma (April 1985): 21-33. 
Kwik Kian Gie went further than Wibisono to defend monopolies. He argued that most critics are not consistent if they blame only the privately owned monopolies while accepting the state monopolies. If the state monopolies are justified on the grounds of their public service, the private monopolies should also be given credit for their pioneering contribution to developing capital-intensive industries and meeting consumer needs. In his view, it was not economic reasoning but "social jealousy" (kecemburuan sosial) that stirred up discontent with monopolies. He was extremely straightforward to point out that social jealousy is inflated because most privately owned monopolies involve non-pribumi business people. To be fair, he suggested, the issue should be the general question of rich and poor or of big and small capital, instead of a racial one. He then concluded, "In a stable and well-ordered country, the absence of monopolies is ideal. ... [But] when can Indonesia reach this situation?" ${ }^{41}$ He thus suggested clearly that monopolies will be inevitable and necessary until the Indonesian economy becomes sufficiently industrialized. ${ }^{42}$

Another term that surfaced in the economic and business circles was "national assets" (kekayaan nasional or asset nasional). In Panglaykim's definition, "[t]he development of national businesses in Indonesia, which consist of family-owned groups, and which place themselves in the world of the national and the international economy, can be termed national assets." He went on to argue that "[i]n the process of their growth, they not only increase employment opportunities but also act as implementers of development programs if the business climate is enticing." 43 Now, the stress was placed on the contribution big business people could make toward creating jobs, paying taxes, earning dollars, promoting entrepreneurship, and, in general, developing the national economy.

Indirectly criticizing the government-proposed bapak angkat system, the economist Thee Kian Wie, whose concern for economic equality was well known, joined to caution that big companies may help small ones by giving subcontracts but that this should not be considered a long-term solution. Thee suggested that the best and final means to achieve economic equality was education and management training. He pointed out that "Indonesian society should instead be oriented toward an economy that is not spiritual[ly based]," and that "[t]hey [small-scale pribumi businessmen] should be able to behave as the nonpribumi group does now." 44 No doubt, by the "economy that is not spiritual (ekonomi bukan spiritual)" he meant a capitalist economy and expressed it only circuitously because of the widespread suspicion of the latter term in Indonesia. His direct reference to the Chinese as rational economic actors is surprising but, considering that Thee is himself a peranakan Chinese, such negative perception of pribumi entrepreneurs may well have been shared, widely and regardless of ethncity, by the business community.

The rejuvenated mood of private capitalism is also evident in a blooming of the business press, which has been a phenomenon since the early 1980s. Several business newspapers and magazines have come into being, escalating such a mood. Probably its most markea

\footnotetext{
${ }^{41}$ Kwik Kian Gie, "Monopoli dan Kecemburuan Sosial," Prisma (April, 1985): 48.

${ }^{42} \mathrm{As}$ an active member of the opposition Indonesian Democratic Party (PDI), Kwik is an outspoken critic of the New Order state's authoritarian rule, corruption, development strategy, and cultural policy. His consistently liberal position on these issues is rare among peranakan Chinese. He is also famous for a direct and logical style of debate. For his strong defense of Chinese capital and big capital, see Kwik Kian Gie, "Non-Pribumi, Dominasi Ekonomi dan Keadilan Sosial," Kompas, June 23, 1978 and idem, "Kapitalis dari Gang Ribald," Tempo, August, 1986 , respectively.

${ }^{43}$ Panglaykim, Bisnis Keluarga: Perkembangan dan Dampaknya (Yogyakarta, Indonesia: Andi Offset, 1984), p. 3; see also Tempo, March 31, 1984, p. 66.

${ }^{44}$ Sinar Harapan, October 3, 1980 (emphasis mine).
} 
consequences are opening up Indonesian business and, thus, implicitly promoting a capitalist value that business is also a virtue. Not only the business press has a professional interest in an open business atmosphere but also its major owners themselves are tied to business interests. Although such sensationalist magazines as Jurnal Ekuin, Fokus, and Expo, were closed by the government, several economic and business dailies, magazines, newsletters, and journals, such as the Business News, Bisnis Indonesia, Neraca, Eksekutif, Swasembada, Forum Ekonomi, Indonesian Commercial Newsletter, and Informasi, have flourished with a professional approach to economic and business issues.

For all the rhetoric, new concepts, and apparent changes in journalism, it is too soon to predict that the ideological campaign will have a significant and marked impact on the precapitalist culture of ordinary Indonesians, particularly in the numerically dominant rural sector. Capitalist hegemony in Gramsci's sense will be established only by the fundamental transformation of the economic and social structures of Indonesia. A long and intense struggle between new and old ideologies will be waged in the process. It is also premature to conclude that the Indonesian state has already committed itself fully to the capitalist pattern of economic growth in that capitalist development undermines the state's own dominance and autonomy. The New Order state's support for the new capitalists and their mouthpiece, intellectuals, could be seen as its temporary accommodation to the economic recession and the consequent fiscal crisis facing the state. These doubts and cautions notwithstanding, it is safe to argue that the Indonesian state has begun to perform one mission of the postcolonial state, namely, creating the hegemony of capitalism-instead of waiting idly for, as John Saul says, "an ideological cement for the capitalist system ... [to] evolve slowly and surely." 45

\section{The Failure of Indigenist Policies and Its Implication}

A more substantive move has been the increasingly evident determination of the policymakers create a "national capitalist class." This position is ironically reflected in the various policies the New Order state initiated in the name of helping the "weak economic group" (golongan ekonomi lemah), which the government defined 46 as the small and medium companies in which pribumi either own at least 50 percent of shares or comprise the majority of the management with capital less than Rp. 25 million for the trading and other service sectors and Rp. 100 million for the construction and industrial sectors. The policies, summarized in table 1, are far more modest, inconsequential, and ineffective than the ones carried out by Suharto's predecessors.

Most of the policies that came out continuously and under various names after 1971 revolved around what Ralph Anspach called credit indigenism. ${ }^{47}$ Anspach characterized the pre-Suharto economic policy making as a frustrating process of increasingly radicalized nationalism. The earlier policies under Parliamentary Democracy were failures, followed by the more radical and more disastrous ones. The earlier policies oscillated between "credit indigenism" and less moderate "decree indigenism." The former method favored the "subsidization of indigenous business without further restrictions upon existing or even new alien enterprises," whereas the latter used "the police power of the state to intervene directly in the market for the benefit of indigenous business" by either allowing "only entry

\footnotetext{
${ }^{45}$ Saul, "State," p. 170.

46 Reported in Antara, June 7, 1979.

${ }^{47}$ Ralph Anspach, "Indonesia," in Underdevelopment and Economic Nationalism in Southeast Asia, ed. Frank H. Golay, Ralph Anspach, M. Ruth Pfanner, and Eliezer B. Ayal (Ithaca, N.Y.: Cornell University Press, 1969). See also, Dorodjatun Kuntjoro-Jakti, "The Political-Economy of Development: The Case of Indonesia under the New Order Government, 1966-1978" (Ph.D. diss., University of California, Berkeley, 1981), pp. 225-38.
} 


\section{Table 1}

The New Order State's Policies to Promote Pribumi Entrepreneurship

\begin{tabular}{|c|c|c|c|}
\hline Year & Institution/Program & Implementing Agencies & Content \\
\hline 1971 & P.T. Askrindo ${ }^{a}$ & Bank Indonesia & $\begin{array}{l}\text { Insurance on bank loans to the } \\
\text { small and medium firms }\end{array}$ \\
\hline 1972 & P.T. Upprindo $b$ & $\begin{array}{l}\text { Bank Indonesia/Dutch } \\
\text { government }\end{array}$ & $\begin{array}{l}\text { Financing small and medium } \\
\text { firms }\end{array}$ \\
\hline 1973 & P.T. Bahana & Bank Indonesia & $\begin{array}{l}\text { Equity financing (to } 12.5 \% \text { ) and } \\
\text { managerial assistance }\end{array}$ \\
\hline 1973 & KIK/KMKPed & $\begin{array}{l}\text { Bank Indonesia; state banks; } \\
\text { regional development banks }\end{array}$ & $\begin{array}{l}\text { Small fixed investments and } \\
\text { financing working capital }\end{array}$ \\
\hline 1974 & DSEN decisione & None & $\begin{array}{l}\text { Restriction on foreign investment } \\
\text { and earlier transfer of PMA shares } \\
\text { to pribumi partners }\end{array}$ \\
\hline 1974 & Kredit Mini & $\begin{array}{l}\text { Bank Indonesia; state banks; } \\
\text { regional development banks }\end{array}$ & $\begin{array}{l}\text { Small credit to small rural } \\
\text { enterprises (up to Rp } 100,000 \text { ) }\end{array}$ \\
\hline \multirow[t]{2}{*}{1975} & Proyek BIPIK & $\begin{array}{l}\text { Bank Indonesia; World Bank; } \\
\text { Department of Industry }\end{array}$ & $\begin{array}{l}\text { Management training to small } \\
\text { entrepreneurs }\end{array}$ \\
\hline & Pegalg & $\begin{array}{l}\text { Department of Trade; } \\
\text { universities }\end{array}$ & $\begin{array}{l}\text { Management training to small } \\
\text { entrepreneurs }\end{array}$ \\
\hline 1976 & KCK/Inpres Pasar ${ }^{h}$ & $\begin{array}{l}\text { Budgetary allocation via } \\
\text { BUUDs }^{i}\end{array}$ & Small credit to rural traders \\
\hline 1977 & P.T. Danareksa & & $\begin{array}{l}\text { Promotion of equity participation } \\
\text { by pribumis in PMAs }\end{array}$ \\
\hline 1977 & DSPi & $\begin{array}{l}\text { Department of } \\
\text { Industry/BKPM }\end{array}$ & $\begin{array}{l}\text { Restriction on PMA and PMDN } \\
\text { investments }\end{array}$ \\
\hline 1979 & Keppres no. 14 & $\begin{array}{l}\text { Government agencies; public } \\
\text { companies }\end{array}$ & $\begin{array}{l}\text { Giving priority to small pribumi } \\
\text { suppliers and contractors to the } \\
\text { government }\end{array}$ \\
\hline 1980 & Keppres no. 14A & State banks & $\begin{array}{l}\text { Credit to the Keppres no. } 14 / 1979 \\
\text { recipients }\end{array}$ \\
\hline
\end{tabular}

Notes: Abbreviations:

askrindo (Asuransi Kredit Indonesia): Indonesian Credit Insurance Ltd.

bUpprindo (Usaha Pembiayaan Pembangunan Indonesia): Indonesian Development Finance Company

CKIK (Kredit Investasi Kecil): Small Investment Credit

dKMKP (Kredit Modal Kerja Permanen): Permanent Working Capital Credit

eDSEN (Dewan Stabilisasi Ekonomi Nasional): National Council for Economic Stabilization

fProyek BIPIK (Proyek Bimbingan dan Industri Kecil): Small Industry Guidance and Development Project

gPegal (Pengusaha Golongan Ekonomi Lemah): Weak Economic Group Entrepreneur

${ }^{h_{K C K}}$ (Kredit Candak Kecil): Small Trader Credit

jBUUD (Badan Usaha Unit Desa): Village Working Unit

iDSP (Daftar Skala Prioritas): Investment Priority List

kBKPM (Badan Kordinasi Penanaman Modal): Capital Investment Coordinating Board. 
into a sector to members of the indigenous group," or more extremely, by excluding "all aliens from a sector by licensing arrangements." 48 The most extreme form of decree indigenism in the pre-Suharto era was best illustrated by the Benteng program. It designated certain categories of commodities (increased from about 10 percent of total imports in 1950 to 85 percent in 1954) to be imported only by bangsa Indonesia asli (native Indonesians). Although this program was supported by bank credit, it created a large number of "briefcase importers" and a very limited number of bona fide importers. ${ }^{49}$ It faded out by 1957. In frustration arising from a series of failed programs, Sukarno mobilized nationalist forces to turn to the most radical form yet. This extreme radicalism was epitomized in the nationalization campaign of 1958. But the nationalization, in Anspach's words, simply "reflected the priority goal of indigenism rather than socialism." 50

In the New Order, most policies were in the line of credit indigenism. Typically, the government set up companies and sanctioned state banks to finance, coinvest in, or provide cheap loans to small and medium companies owned by pribumi (P.T.'s Askrindo, Upprindo, and Bahana). Otherwise, it introduced education programs to train managers and entrepreneurs (Proyek BIPIK and Pegal), Between 1973 and 1976, several credit systems were created to provide part of the capital financing needed by pribumi businessmen to set up and run new companies (KIK and KMKP) or to help the rural enterprises and traders compete with the Chinese middlemen (KCK and Inpres Mini). By no means, however, did these institutions and programs directly infringe upon the dominance and vested interest of the big businesses.

In the past two decades, the New Order state's pribumi-supporting policy was closely associated with the condition of the national economy. More precisely, it is largely the affordability of the economy and the state budget that have determined the course of the state's action in responding to "nationalist" demands by small pribumi capitalists and their political supporters. In other words, economic recessions and fiscal difficulties of the state that must have doubled the hardship of small industries, in fact, brought about few meaningful policies despite their louder complaints and greater demands. For the first few years of the New Order, while the economy was busy recovering from the consequences of Sukarno's mismanagement and laying groundwork for full-fledged development, small capital received little attention, and, in fact, few protests were heard. Since 1982, the sense of economic crisis felt by both the state and the business community has overwhelmed the outcries of the desperate small capitalists. The mood certainly has favored moving toward antistatism and a free-market economy, as discussed.

It was, thus, during the best years of the Indonesian economy, the 1970s, that the state worked on the demands of the indigenous entrepreneurs. The latter half of the 1970s witnessed the revival of decree indigenism, although on a far smaller scale than that of the sweeping Benteng program of the early 1950s. The catalyst was the Malari affair of 19731974, which made an issue of economic domination by foreign capital and corrupt associations between the leadership and the Chinese cukong. The decision in early 1974 by the Board for the Stabilization of the National Economy (Dewan Stabilisasi Ekonomi Nasional) yielded a guideline for restricting foreign investment and speeding up the foreign investor's transfer of the majority shares to the domestic partners. But real action did not follow until

\footnotetext{
${ }^{48}$ Anspach, "Indonesia," pp. 123, 124.

${ }^{49}$ lbid., pp. 167-79. See also, John O. Sutter, Indonesianisasi: Politics in a Changing Economy, 1940-1955, 4 vols., Data Paper no. 36 (Ithaca, N.Y.: Department of Far Eastern Studies, Cornell University, 1959), chap. 24.

${ }^{50}$ Anspach, "Indonesia," p. 126.
} 
1977 when P. T. Danareksa, a national trust fund, was established. Danareksa would function as "an issuing house and underwriter as well as one of the most important stockholders." 51 But because the scheme counted on Jakarta's dormant stock market and because no antimonopoly regulations were yet in effect in Indonesia, its failure was guaranteed.

If there has been any notable success with decree indigenism, it was achieved by the more forceful Keppres no. 14/1979 and its ensuing Keppres no. 14A/1980, which were later superseded by Keppres nos. 29/1984 and 30/1984. The presidential decisions gave the weak economic group a priority or exclusive status to receive certain government contracts. For government projects and purchases valued under Rp. 25 million, only the weak group would be allowed to participate in its tender. For the range between Rp. 25 million and Rp. 50 million, the government would give a 5 percent premium on the price bid by the contractor belonging to this category. Although this program recorded modest success for the first few years, the ill timing of its launch just before the post-oil boom recession diminished its effectiveness. Furthermore, the typical problems with government-sanctioned policies, such as corruption, confusion of interpretation, lack of interdepartmental coordination, Ali-Baba firms, and abuse by big companies, were widely reported in the first year of the program. 52 Yet the most telling fact is that this policy did not and was not intended to discourage the growth of the big business sector. Suharto himself underscored that Keppres no. 14A/1980 did not mean to discourage "the role of the strong economic group" but only to "give the weak economic group opportunities and guidance to become strong." ${ }^{23}$ In fact, the economic sectors that benefited the most from the policy were contracting and construction, which had long been congested by small and medium firms and were represented quite strongly by state-owned and a few indigenously owned companies.

As the foregoing evidence indicates, the significance of the New Order state's pribumipromotion policy has been undercut by its preference for credit indigenism and by the minimal impact of decree indigenism on the dominance of big business. My second argument to the same effect is based on the almost negligible government spending and bank credit allocated to the colorfully titled programs. For example, the KIK/KMKP credit was awarded to 377,529 cases totaling Rp. 203,285 million for the first four years since they were implemented. ${ }^{54}$ If one considers that the credit took the forms of fixed investments and working capital, it is doubtful that slightly over 500,000 rupiah (about US $\$ 1,000$ ) per case ever made a significant difference in the overall structure of Indonesian capitalism. For the first six years (as of the end of the fiscal year 1979/80), Rp. 571 billion was allocated in the form of KIK/KMKP and Rp. 20.5 billion in the form of Kredit Mini against Rp. 2.5 trillion of the total bank credit for 1979/80 alone. ${ }^{55}$ Kuntjoro-Jakti gives a similar figure: "By the end of 1978 the total cumulative value of KIK-KMKP-Kredit Mini represented only $6.4 \%$ of the total cumulative value of approved PMDNs." 56

Other programs were even more trivial in their achievements. Kuntjoro-Jakti also found that for the first six years of implementation, P. T. Askrindo provided insurance on a total Rp. 219 billion or Rp. 482,585 per client while P. T. Upprindo carried out only eighty projects

\footnotetext{
${ }^{51}$ Kuntjoro-Jakti, "Political Economy," p. 233.

${ }^{52}$ See, for example, Kompas, October 11, 1979; Antara, August 11, 1979; Pelita, October 24, 1980; Kompas, March 29, 1980.

${ }^{53}$ Quoted in Kompas, July 11, 1980.

${ }^{54}$ Kuntjoro-Jakti, "Political Economy," p. 239.

${ }^{55}$ Antara, June 26, 1980.

56.Kuntjoro-Jakti, "Political Economy," p. 235.
} 
with the Rp. 11.5 billion of equity financing. ${ }^{57}$ The case of P. T. Bahana clearly indicates that the institution was nothing more than a showcase; only ten projects were implemented with Rp. 600 million between 1973 and 1976. Kredit Candak Kulak amounted to Rp. 87.6 billion by September 1980.58

My additional sources of evidence point to the New Order state's soft stance on indigenism. Various problems nullified and distorted the policy objectives, if taken seriously at all, in the implementation stage. Corruption, incompetence, confusion over policies, and abuse besetting both the implementers-government agencies and state banks-and the beneficiaries continued to undermine the cause of such programs. Even if the policy makers were seriously committed at the beginning, the dismal outcome of almost every program that was implemented weakened the position of its advocates. Because no alternatives have been found and because more radical policies had a catastrophic history, the extent and degree of future pribumi-promotion policy are very likely, at most, to remain at the existing level.

In fact, no more policies have been initiated to support the small pribumi business people since the collapse of oil prices. The Keppres nos. 29/1984 and 30/1984 were the last of the ill-fated indigenist programs. Instead, the state's commitment to them have strictly remained within the boundary of pure rhetoric. The cooperative spirit declared in ARTICLE 33 of the Constitution (UUD 45$)^{59}$ has often been stressed but how this ambiguous and declamatory statement could be materialized interested few policy makers, economists, and business people. By 1985, the decision and opinion makers appeared to lean toward the final conclusion that the growth of small pribumi capitalists should be achieved by market forces and submitted to the free will of the business people involved, or to put it more appropriately, the mercy of the strong economic group. ${ }^{60}$

This development now clarifies what purposes the numerous policies actually served. The making of the "unsuccessful" policies was an ideological project the New Order state carried on to cushion the effects of a rapid restructuring of the Indonesian economy in which the new capitalists, along with the military-dominated state, rose to dominance. The policies, which achieved little progress over time, nevertheless had to be created repeatedly, only to make the state appear neutral and above class interests. In the meantime, the repetition of failures demoralized the advocates for such programs and alternative forms of the Indonesian economic system while assuring the new capitalists of the state's commitment to

\footnotetext{
57 Ibid.

${ }^{58}$ Business News, January $29,1980$.

${ }^{59}$ The extremely short and ambiguous article of the Constitution invited the persons involved to use their full imagination in interpreting it to their liking. Clause 1 of ARTTCLE 33 reads: "Economy shall be organized cooperatively" (official translation). The original text in Indonesian has space for more controversies, which is roughly translated as, "Economy shall be organized as a joint venture on the basis of the family spirit" (Perekonomian disusun sebagai usaha bersama berdasar atas azas kekeluargaan). This clause, especially the phrase "joint venture" (usaha bersama), is the only reference to the constitutional foundation of the private sector. Less obscure and more words are instead given to the public enterprise in clauses 2 and 3 of the same article. They read respectively as: "Branches of production which are important to the State and which affect the life of most people, shall be controlled by the State" and "Land and water and the natural riches therein shall be controlled by the State and shall be exploited for the greatest welfare of the people."

${ }^{60}$ From the long-term perspective, however, this conclusion might well be seen as tentative. Unless the ideological project the elites were carrying out in the 1980 s leads to the creation of a capitalist hegemony in its truest sense, indigenist demands will continue to surface. Policy makers, the condition permitting, may yield to such demands. The state's fiscal capacity and the ability of the economy to afford the discriminatory policy meet the condition.
} 
their continued growth. If the state is still in the driver's seat in Indonesia's modernization, the industrial strength the capitalists have already accomplished, the economic predicament that requires a further procapitalist restructuring, and the steady growth of capitalist ethics in Indonesian society all indicate that the formation process of a capitalist class will accelerate, at least, in the foreseeable future. 
